\title{
FEATURES OF ENVIRONMENTAL SAFETY OF THE AGRICULTURAL SECTOR: INFLUENCE ON LEADERSHIP POSITIONS IN THE ECONOMY
}

\author{
Alexander Pishchenko
}

\begin{abstract}
The purpose of the article. In the context of the search for strategies and algorithms to exit the global crisis, particular attention is paid to the development of industry and industrial policy. The agricultural sector has always been considered a priority and strategically important sector for Ukraine, which can meet not only the needs of the domestic market but also the world one. Methodology. To achieve the purpose of the article, a set of general scientific and specific methods of scientific knowledge has been used, in particular: abstract-logical (for substantiation of the research methodology, theoretical generalizations, formulation of conclusions); dialectical, historical-logical, analysis and synthesis, induction and deduction (for determination of the preconditions for ensuring environmental safety of products of the agricultural sector through the development of its innovative potential); statistical-economic (for assessment of the current state of development of the agricultural sector and identification of the factors that affect its environmental safety); strategic and structural-functional analysis (for correction of the strategic directions of the development of innovative potential of agricultural sector to maintain its environmental safety). Results. The formation of a targeted industrial policy aimed at satisfying the domestic needs for quality, environmentally safe food, taking into account the imperatives of sustainable development and environmental protection, should become one of the strategic directions for activation of leadership positions in the international agro-industrial market. The purpose of the article is to substantiate the peculiarities of ensuring environmental safety of products of the agricultural sector. Practical implications. The problems of ensuring environmental safety of the agricultural sector have been identified and the current state and the trends of agricultural sector development in Ukraine have been analyzed. It has been established that the use of imperfect technology and equipment in the food production leads to the introduction of harmful impurities into the final product or the formation of harmful substances during the production process, which, in turn, requires additional innovative measures to solve an actual problem. It has been substantiated that the enterprises of the agricultural sector are characterized by low innovation activity, which is a negative factor for ensuring environmental safety in accordance with world standards and leadership qualities. Value/originality. For increasing the leadership positions of the agricultural sector of Ukraine in order to ensure its environmental safety, it has been proposed to strengthen the effective interaction of all interested parties - the state, agricultural sector enterprises, agricultural producers and research institutions. Such interaction will allow achieving a synergistic effect, strengthening the common opportunities of all parts of domestic production in the creation of competitive technologies for the production of environmentally safe products and accessing to world markets.
\end{abstract}

Key words: agricultural production, ecological safety, economic development, management system, mechanism.

JEL Classification: O17, O32, Q19

\section{Introduction}

One of the important directions of stabilization of the leadership positions of the national economy in the international market is to ensure the health of the nation, including through food products. Today, the environmental safety of food

\footnotetext{
Corresponding author:

${ }^{1}$ Chernihiv Polytechnik National University, Ukraine.

E-mail: pischenko@gmail.com

ORCID: https://orcid.org/0000-0353-8238-8544
}

is a global problem that affects not only health but also the welfare of the state as a whole. In Ukraine, there are no effective mechanisms for eliminating the negative factors influencing food safety. Access to food products, their quality and ecological compatibility affects the level 
of food security of the state, serve as indicators of its social stability. Therefore, the choice of the innovative development direction, ways to overcome the problems of the industry should be based on scientifically based analytical data and clear strategic directions of management of the leadership qualities of the agricultural sector in Ukraine. Thus, the issue on the research of the perspectives for agricultural sector leadership for the comprehensive improvement of the system for ensuring the production of environmentally safe food products, increase in the ecological image of the country and the competitiveness of the agricultural sector on the domestic and foreign markets is relevant.

In accordance with the Law of Ukraine On Quality and Safety of Food Products and Food Raw Materials as amended by the Laws of Ukraine, a safe food product is a food product that does not have a harmful effect on human health, directly or indirectly, in the conditions of its production and circulation with compliance for sanitary measures and consumption (use) by appointment (The Law of Ukraine On Quality and Safety of Food Products and Food Raw Materials As amended by the Laws of Ukraine).

R.I.Shevchenko has paid attention to a thorough analysis of the concept of "environmental safety of food products" and interprets the concept as a characteristic of the set of material, energy and information flows, processes and phenomena that determine and accompany them, and are their consequences and constitute a complete life cycle of food products as a factor that, to some extent, affects the stability of the system "environment-human" and a person directly (Shevchenko, 2015).

S.M. Romanenko notes rightly that environmentally safe products may contain maximum permissible concentrations of harmful substances, thus, pesticides, agrochemicals, plant protection products can be used during its production, and the production of environmentally safe products should be based on organic farming technologies in specially prepared conditions, creating special zones remote from industrial enterprises, in ecologically safe, radioactive contaminated areas, without application of genetic engineering achievements (Romanenko, 2008).

On the basis of the analysis of existing scientific and theoretical approaches, it has been described the essence of the category of "leadership innovative potential of the agricultural sector" as a complex system of ensuring the high quality of products by the agricultural sector enterprises and feedback between industry, science and society in the context of combining financial, intellectual, technical, informational, human capitals, which takes into account the interdependence of technological processes and the qualification level of the personnel.

\section{Results}

Today, unfortunately, we can not talk about the proper state of the environment. The reasons for this are the following: electric power stations, plants and factories emit tons of harmful gases into the atmosphere; content of toxic substances in exhaust gases of cars exceeds the generally accepted norms considerably; industrial enterprises pollute water pools with their sewage and hundreds of hectares of fertile land remain unused. As a result, a lot of agricultural raw materials, suitable for the food and processing industry, hasn 't been obtained, and much of them became dangerous to humans.

However, it is precisely the technology of production, processing and storage of food products is the most dangerous. The use of imperfect technology and equipment in the production of food products leads to the entry of harmful impurities into the final product or the generation of harmful substances during the production process, which, in turn, requires additional socioeconomic measures to solve the problem.

In Ukraine, almost a sixth part of fruit and vegetables contains nitrates in doses that exceed the maximum acceptable level. In the first place, excessive nutrient content in food products contributes to the development of cancer and allergic diseases. Excessive nitrate in fruit and vegetables is not only a consequence of improper use of nitrogen fertilizers but also the result of the sorption of nitrogen oxides directly from the atmosphere, which are formed during combustion of different types of fuel. Insufficient lighting and thickening of crops are the main causes of excessive nitrates in vegetables from the covered ground (greenhouses, hotbeds, etc.) (Velychko, 2011; Nyzhnyk, 2013; Novoitenko, 2016).

Particular attention should be paid to the threats that arise as a result of an increase in the total volumes of mineral fertilizers and, in turn, reduction of organic fertilizers (Table 1) 
(use of organic fertilizers, which are the main source of replenishment of nutrient reserves in the soil, increase of humus content, as well as the conservation and extended reproduction of soil fertility, tend to decrease). During 2017, the average level of manure maintenance in soil reached $0.5 \mathrm{t} / \mathrm{ha}$, while to maintain the necessary humus content, its value should be within the range of 8-14 $t /$ ha depending on the natural conditions and geographic location of the land resources. This situation arose as a result of a decrease in livestock development and a reduction in the efficiency of harvesting and storage of waste.

The most important place in ensuring the environmental safety of food products takes the State Service of Ukraine for Food Safety and Consumer Protection. However, for today, this authority is assigned too many tasks in various spheres, which does not allow specialized activities. In addition, until recently, control over the production was carried out at the stage of readymade products, which was not a guarantee of environmental safety in general.

It has been established that efficient, highly productive, dynamically growing agricultural sector is a priority in ensuring the economic security of the state and achieving the leadership of national competitiveness. The term "development of industry" should be understood as a set of quantitative and qualitative changes that involve the transition from one qualitative state to another in conditions of different factors influencing the internal and external environment. Domestic agricultural sector comprises 22 specialized branches, which includes more than 40 major industries. Among the leading industries are the following; meat, oil and fat, confectionery, milk, alcohol, flour, and sugar. In the structure of food production, the biggest share, over $27,94 \%$, is attributed to the products of the oil and fat industry, $13,3 \%$ - meat and meat products, $10,5 \%$ - dairy products, $11 \%$ - beverages.
From 2010 to 2017, the volumes of agricultural sector sales increased by 188975 million UAH $(+93 \%)$. The share of profitable enterprises in comparison with 2010 increased by $8.3 \%$. But this did not improve profitability. By 2012, net income had a positive growth dynamics, however, during 2014-2017, the rate of decline in profits amounted to an average of $3.1 \%$ annually. 2015 was the most unprofitable for the industry. Operating profitability was at an average level and increased by $1 \%$ annually from 2010 to 2015 , except in 2017. Furthermore, during the research period, the average salary increased by 3 times and the productivity doubled. However, the number of workers and enterprises engaged in the agricultural sector has decreased by $21 \%$ and $25 \%$, respectively, for the past six years, and this fact is a very negative sign, taking into account the growing unemployment rate and the share of industry in Ukraine's GDP.

Calculations show that in order to create a modern highly developed agricultural sector, the country, needs 20-25 billion UAH of investments. Funding can be made at the expense of foreign and domestic investors, depreciation deductions for reproduction of production potential, bank and tax credits and other sources. Capital investments should be directed primarily to strategic industries, in particular, sugar, oil and meat, canned fruit and vegetables, alcoholic beverages, wine-making, salt and others, which can produce competitive products for the domestic and foreign markets. Due to investments, production capacities and fixed assets are expanded and improved, and the necessary proportions are provided. Investments in the production sphere should ensure the increase in the technical level and the improvement of the location of existing industries, as well as the necessary increase in capacity. It is necessary to make investment decisions on optimization of the structure of assets, determination of the need for their replacement or liquidation; development

Table 1

Dynamics of Use of Organic Fertilizers in Ukraine in 1990-2017

\begin{tabular}{|l|c|c|c|c|c|c|c|}
\hline & 1990 & 2000 & 2005 & 2010 & 2016 & 2017 & 2017 to $1990(\%)$ \\
\hline Use of organic fertilizers, mln tons & 257 & 28.4 & 13.2 & 9.8 & 9.9 & 9.6 & 3.7 \\
\hline $\begin{array}{l}\text { Use of organic fertilizers per ha } \\
\text { of agricultural land, tons }\end{array}$ & 8.6 & 1.3 & 0.8 & 0.5 & 0.5 & 0.5 & 5.8 \\
\hline $\begin{array}{l}\text { Share of area treated with organic } \\
\text { fertilizers in total agricultural land, \% }\end{array}$ & 18.0 & 3.3 & 2.7 & 2.1 & 2.2 & 2.5 & 13.9 \\
\hline
\end{tabular}

Source: (Semenenko, 2017; The Official Website of the State Statistics Service of Ukraine) 
of methods and means of implementation of investment policy; determination of the need for financial resources; development and approval of investment projects. Therefore, an important stage of the research is the identification of the main factors that influence the investment activity in the agricultural sector and characterize its state and development prospects.

From 2012 to 2017, capital investment in the development of the industry had different dynamics. The growth rate from 2012 to 2014 was $10 \%$ - $12 \%$. In 2015 , the volume of capital investments decreased by $12 \%$, in 2016 it remained at the level of 2015, however, in 2017 it increased by 25\% (Figure 1). The main reasons for the decrease in investment activity in the agricultural sector in recent years were the following: economic crisis, inflationary processes; reduction of investment expenditures with the growth of financing of investments from own and borrowed funds of enterprises; unstable financial situation of enterprises of the agricultural sector; lack of state investment strategy; imperfection of legislation.

The agricultural sector enterprises are characterized by low innovation activity, which is a negative factor for the development of socioeconomic aspects in the agricultural sector, and as a result, low economic efficiency. The number of introduced innovation processes and the names of innovative products decreased by $48 \%$ and $40 \%$, respectively, from 2013 to 2015. The volume of financing of innovation in 2013 amounted to 1700695 thousand UAH, including $0.003 \%$ from the state budget, $86.7 \%$ from own funds, and $8 \%$ and $5 \%$ accounted for foreign capital and loans. In 2014, the volume of investment in innovation activity increased by $27.8 \%$ compared to 2013 . At the same time, the investment of foreign investors and the state practically disappeared, the share of own investments decreased by $5 \%$, but the financing of agricultural sector enterprises increased at the expense of loans by $13 \%$. In 2015 , the volume of financing of innovation activity of the industry decreased by $30 \%$ and by $9.5 \%$ in comparison with 2013. In the financing structure, almost all finances consisted of own funds (95.9\%), the share of loans decreased by 401.5 million UAH, but new sources of financing appeared: from local budgets at the level of $0.02 \%$, which is much more than financing of the development of innovation activity from the state budget.

\section{Discussions}

Growth in the production of innovations in the industry leads to an increase in its exports and does not lead to saturation of the domestic market with this kind of products, the potential of which Ukrainian experts estimate at the level of 80 billion UAH. This increases the risks associated with the fact that domestic market needs will be met by

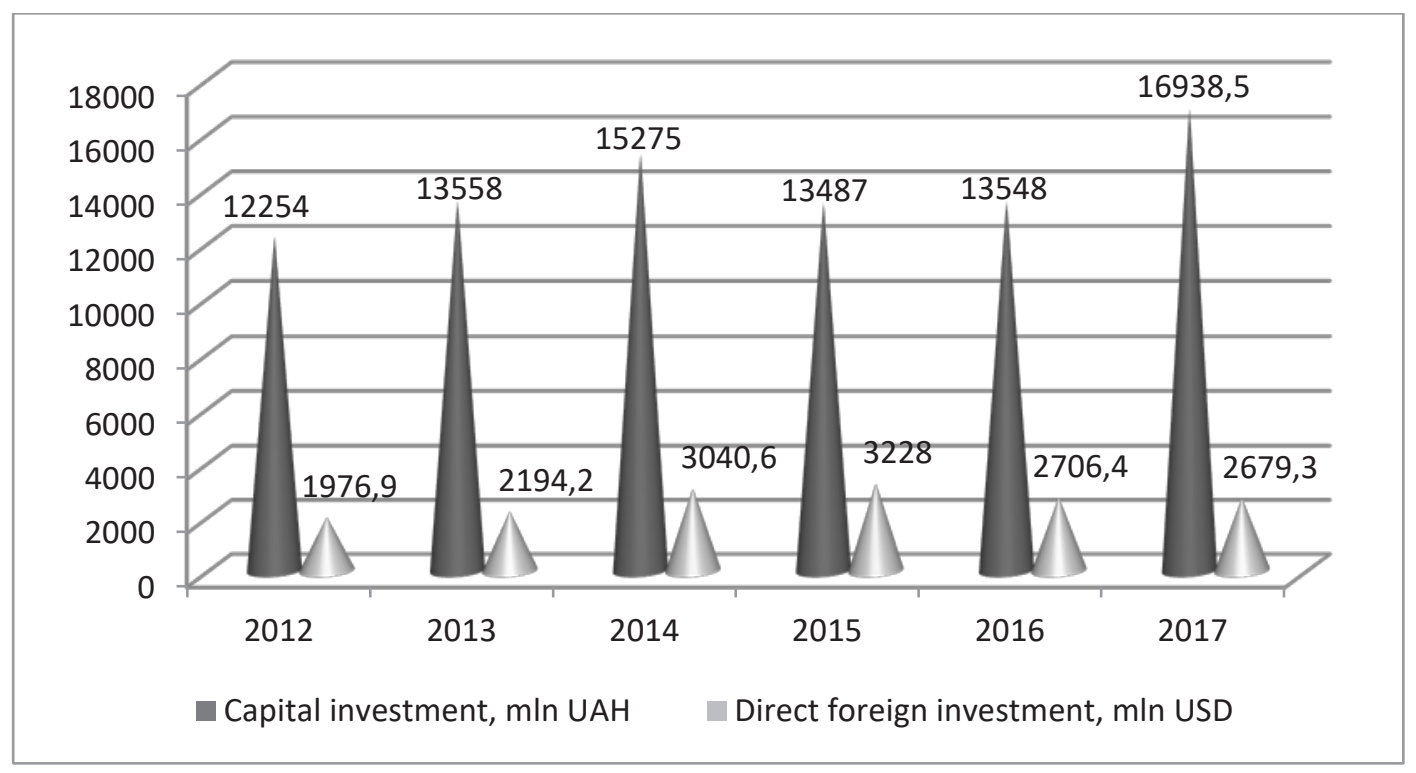

Figure 1. Dynamics of investment in the agricultural sector of Ukraine in 2012-2017

Source: (The Official Website of the State Statistics Service of Ukraine) 
increasing imports of cheaper, deep-processed products to Ukraine.

The analysis of the development of the agricultural sector in Ukraine allowed substantiating the current problems of stabilizing the leading positions in the economy. These problems include: state regulation of prices and profitability of agricultural sector enterprises; lack of state support for the renewal of fixed assets; lack of loyal innovation and investment climate for the development of the agricultural sector; legal and regulatory framework that needs to be updated in accordance with the socio-economic changes taking place in the country; weak development of infrastructure and logistics system; high cost of production; lack of effective marketing activity; weak interaction of agricultural producers of raw materials, processing enterprises, trade intermediaries, suppliers on the basis of cooperation; ineffective control system, etc.

Taking into account existing tendencies and problems of functioning of the agricultural sector of Ukraine, the priority ways of its leadership for ensuring environmental safety are the following: improving product quality; constant renewal and increase in a range of products; expanding target markets. The agricultural sector enterprises can act as innovators, that is, to use new technologies and developments to create and improve products that meet the needs of the modern consumer. The benefits of this solution are that the producer obtains the opportunity to become a leader, on the other hand, he bears a certain cost on scientific development, that is, bears the risk associated with a possible failure in the market with new products. The factors that negatively influence the effectiveness of the development and introduction of a new product are the following: insufficient or poor quality of products; discrepancy of the new products with the requirements of the market; insignificant advantages over competitors' products; unpredictable reaction of competitors; insignificant segment of the market or change of segments of consumers; unsuccessful positioning on the market; weak support from distribution channels; changes in the macro environment; insufficient level of profitability; organizational problems, etc.

It has been substantiated that an important strategic direction for stabilization of the agricultural sector leadership of Ukraine to ensure its environmental safety is the establishment of effective interaction of all interested parties - the state, agricultural sector enterprises, agricultural producers and research institutions. The first priority is the need for the formation of sustainable development of agricultural producers and the modern agricultural sector. The complex of measures should settle the matters on increasing the volumes of the production of high ecological quality raw materials, increasing the technical level of food and processing enterprises, creating fundamentally new environmentally safe technologies for food production. It is advisable to form an effective partnership based on the geographical location of business entities. Therefore, it is necessary to form and implement the new model for the state regulation of the formation and development of the innovative potential of the agricultural sector of Ukraine. It should be based on the complex interaction between the state, agricultural sector enterprises, agricultural producers and research institutions. The proposed model, which includes the project, functional, resource, organizational and managerial components of the innovation potential of the agricultural sector, will provide an opportunity to obtain significant economies on the scale of production of environmentally safe products, as well as to reduce costs on packaging and production of new products, to create the necessary conditions for the interaction of science and production. Such interaction will allow achieving a synergistic effect, strengthening the common opportunities of all parts of domestic production in the creation of competitive technologies for the production of environmentally safe products and access to world markets.

\section{Conclusions}

Nowadays, most food products produced in Ukraine can not act as leaders in the world market due to the inadequate control both over emissions to the natural environment and at all stages of food production. Ukrainian production does not use rich international experience and is characterized by high financial costs, which is not profitable for our country due to the absence of state support. Therefore, drawing attention to food production safety by improving the state policy for the development of the innovative potential of the agricultural sector should be one of the priority tasks for Ukraine. The main indicators of agricultural sector development have been 
analyzed. It can be noted that the agricultural sector is a rather promising and competitive industry over the past few years. Its production and export potential is powerful and has a strategic impact on the formation of Ukraine's GDP. The decline in the efficiency of financial and economic activity in the last seven years is mainly observed by individual sub-sectors, product subgroups. The main reasons for such tendencies are the following: economic and political situation in the country and the world as a whole; state of raw material base and purchasing power of the population; lack of working capital; lack of clear innovation policy; high cost of foreign technologies. The new model for state regulation of the leading positions of agricultural sector of Ukraine has been proposed, which is based on the complex interaction of the state, agricultural sector enterprises, agricultural producers and research institutions. It has been noted that implementation of this model will allow achieving a synergistic effect, strengthening the common opportunities of all parts of domestic production in the creation of competitive technologies for the production of environmentally safe products and access to world markets. Organization of the process for formation of a coherent vision of the leadership of the agricultural sector in Ukraine for all interested groups of participants through consolidation of public opinion will allow state authorities to react in a timely manner to changes in the development of the agricultural sector and to adjust industrial policy taking into account their interests and the needs of the system of ensuring environmental safety.

\section{References:}

The Law of Ukraine On Quality and Safety of Food Products and Food Raw Materials As amended by the Laws of Ukraine. The Official Bulletin of the Verkhovna Rada of Ukraine). 2005. No. 50. Art. 533.

Shevchenko, R. I. (2015). Environmental safety of food products: definition of the concept. Food Science and Technology, vol. 1, pp. 65-70.

Romanko, S. M. (2008). Economic and legal mechanism for providing environmental safety of agricultural products: Author's Abstract ... Candidate of Juridical Sciences: 12.00.06. Kyiv: National Agrarian University.

The Official Website of the State Statistics Service of Ukraine. Retrieved from: http://www.ukrstat.gov.ua Velychko, O. V., Dubovykov, M. M., \& Liashchenko, O. V. (2011). Mechanism for formation of the national investment and innovation system of Ukraine: monograph. Luhansk: Elton-2.

Nyzhnyk, V. M. (2013). Mechanisms for increasing the competitive potential of industrial enterprises: monograph / edited by the Doctor of Economic Sciences, Prof. V. M. Nyzhnyk, Candidate of Economic Sciences, Associate Professor M. V. Nikolaichuk. Khmelnytsky: KhNU.

Novoitenko, I. V., Slobodian, N. Ya., \& Malynovskyi, V. V. (2016). Prospects for the development of the agricultural sector in Ukraine. Global and National Problems of Economy: collections of scientific works, vol. 11, pp. 454-460.

Semenenko, O. H. (2017). Analysis of agricultural sector development in Ukraine. Economic Herald of the University, vol. 33(1), pp. 168-182. 